\title{
ORIGIN OF ANTIBODY VARIATION
}

\author{
By DR. S. BRENNER and DR. C. MILSTEIN \\ Medical Research Council Laboratory of Molecular Biology, Hills Road, Cambridge
}

VARIaTion of the structure of both $\%$ (refs. 1-3) and $\lambda$ (ref. 4) light chains of antibody molecules appears to be confined to the $\mathrm{N}$-terminal halves of the proteins while the C-terminal sequences are invariant. All theories of the origin of the variation of antibody proteins must account for this remarkable structural feature of the molecules. Lederberg ${ }^{5}$ proposed that the variety of antibodies is a consequence of a high rate of mutation confined to a few genes in the somatic line of antibody producing cells. It is generally believed that hypermutation theories are unlikely to be correct because of the difficulty of defining a mechanism which operates only on part of a gene $^{6}$. The emphasis has therefore been placed on hypotheses which realize the observed restriction of sequence changes by postulating genetic incorporation or poly. peptide fusion. Smithies ${ }^{7}$ has proposed that the information specifying the variable region is earried by a virus which integrates into a gene determining the invariable region. In an analogous theory, Dreyer and Bennett ${ }^{8}$ suggest that the constant region is specified by a virus or episome which is incorporated into many different genetic sites. Another suggestion is that the two halves of the polypeptide chains may be independently synthesized and then joined together by a peptide bond, perhaps by a specific enzyme $e^{9,10}$. One may generalize these and other theories by saying that two fragments of $(a)$ DNA, $(b)$ RNA or $(c)$ protein are joined together to provide information for, or to make, the complete polypeptide chains. In addition, most of the mechanisms imply that many different genes will ultimately control the variable part of the antibody molecule.

In this article we resurrect the hypermutation theory by suggesting a mechanism which allows the mutational acts to be restricted to specific regions of a few genes. In general terms, we propose that part of the nucleotide scquence of the gene specifying the invariable region acts as a recognition site for an enzyme which cuts the DNA. During repair of this local region errors are introduced at random at a high rato to generate a large number of different sequences. There are many variants of this general hypothesis, but it is useful to examine one in detail. This is shown in Fig. 1 where we consider a gene specifying one of the light chains. The messenger RNA carrying this information will be copied from one of the chains of DNA and will therefore have the same sequence as the complementary chain. The absolute polarity is given by the direction of translation of the messenger, that is, the $5^{\prime}$ end corresponds to the $\mathrm{N}$-terminal end of the polypeptide chain ${ }^{11-13}$. We assume that a cleaving enzyme recognizes the nucleotide sequence on the DNA corresponding to part of the invariable sequence of the light chain near the variable region, and cuts one of the strands of the DNA, exposing a free $3^{\prime}$ end. An exonuclease then degrades the DNA, exposing a stretch of the complementary strand. The gap is then repaired by a polymerase and, during this repair, crrors are introduced. These could be base pairing mistakes or additions or deletions. In this particular scheme, the trimming and repair are carried out by enzymes with the same mechanism of action as exonuclease III and DNA polymerase isolated from bacteria ${ }^{14-16}$. Enzymes with opposite polarity, trimming and repairing from the 5 ' end, have not yet been found. In the proposed mech. anism the right-hand end of the variable region is definitively fixed by the point of cleavage. We do not need to postulate a specific location for the left-hand end. For example, the polymerase may displace the exonuclease when enough single stranded DNA has been generated for it to bind sufficiently strongly to initiate repair. It is therefore possible that, on the average, the repaired length may only rarely include the extreme left-hand region, and this would be reflected in the clustering of errors towards the centre of the molecule.

It is obvious that repeated repair of the region cannot in general lead to the accumulation of errors. Furthermore, while the region of the gene subject to repair corresponds to the $\mathrm{N}$-terminal half of the protein, the DNA strand repaired is not the one which is copied into messenger RNA. Therefore, in order to express and stabilize the changes the cell must divide and the DNA must be replicated in the normal manner. One of the cells produced is like the original type, the other contains a mutant sequence. Repetition of the process could therefore generate a very large number of different sequences, but it is interesting to note that every sequence produced, including the primordial one, is also conserved. Exactly how many division cycles are necessary to generate the deviations in sequence would depend on the mutagenic rate of the repair polymerase.

The mutation process depends in the first instance on the presence of the cleaving enzyme, and both it and the polymerase may only be expressed at specific stages of the differentiation of antibody precursor cells. Further steps of differentiation could stop the sequence of events by destroying or inhibiting the cleaving and/or repair

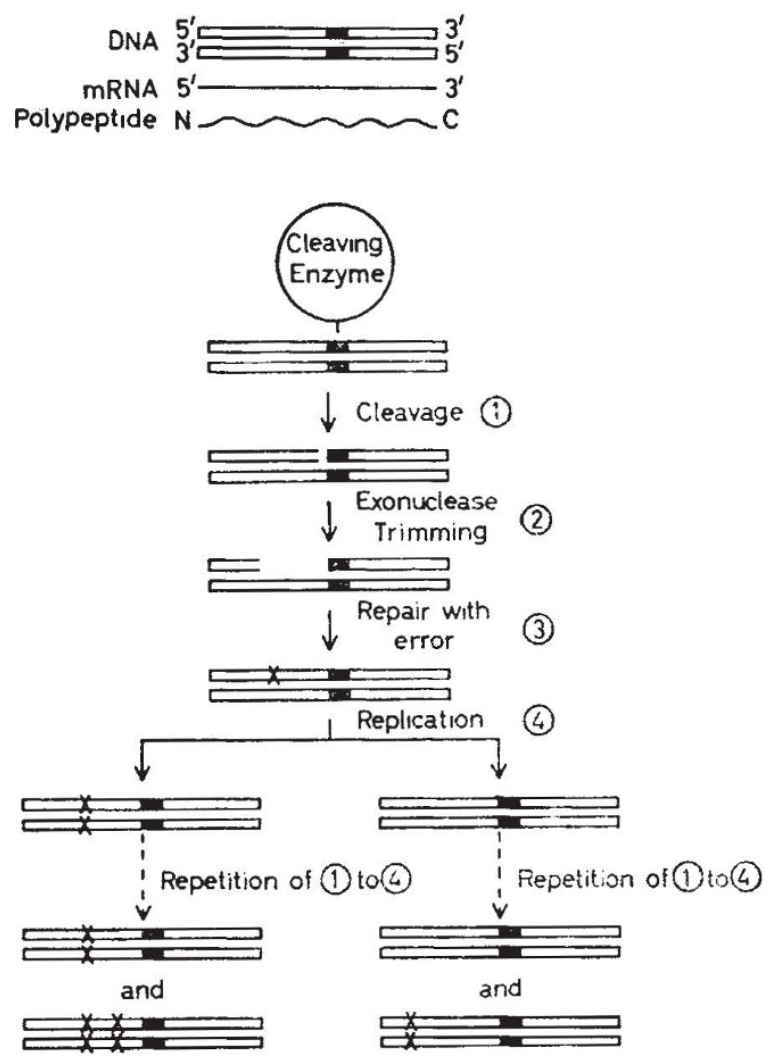

rig. 1 
enzymes. The subsequent clone produced from such a cell could therefore be genetically uniform and stable. As suggested by Lederberg ${ }^{5}$, the immune response could involve selection of such clones by antigens.

The mechanism proposed has precedents in other biological systems. Excision and subsequent repair of DNA occurs after radiation damage in micro-organisms ${ }^{17-19}$. Specific recognition of DNA sequences for cleavage and chemical modification is the basis of host restriction and modification of bacterial and bacteriophage genomes ${ }^{20}$. Mutant DNA polymerases in bacteriophage T4 produce high frequencies of errors $^{21}$ and an altered DNA polymerase may be responsible for the elevated mutation rate of one strain of $E$. coli ${ }^{22}$

We cannot propose a definitive test of this theory apart from the direct demonstration of a cleaving enzyme and a mutagenic polymerase in precursor cells, which may not be easy to do. One prediction is that the heavy chains of antibody molecules will have the same features as the $\mathrm{L}$ chains and, in particular, the junctional region should contain the same recognition site. We note, however, that this site must only have the same nucleotide sequence, and the amino-acid sequences of this region in $\mathrm{H}$ chains may not be the same as that in $\mathrm{L}$ chains but may be related to it by a phase shift. Unfortunately, this result, though striking, would only show that recognition occurs at the level of nucleic acid and would still be consistent with genetic incorporation models. Our main purpose in proposing this theory is to show that a mutational origin of anti- body variation is consistent with the known facts and that we are not compelled to postulate more elaborate models.

${ }^{1}$ Hilschmann, N., and Craig, L. C., Proc. U.S. Nat. Acad. Sci., 53, 1403 (1965).

2 Titani, K., Whitley, E., Avogardo, L., and Putnam, F, W., Science, 149,

${ }^{3}$ Milstein, C., Nature, 209, 370 (1966).

${ }^{4}$ Milstein, C., J. Mol. Biol. (in the press).

" Lederberg, J., Science, 129, 1649 (1959).

' Hood, L. E., Gray, W. R., and Dreyer, W. J., Proc. U.S. Nat. Acad. Sci., 55, 826 (1966).

'Smithies, O., Science, 149, 151 (1965).

${ }^{8}$ Dreyer, W. J., and Bennett, J. C., Proc. U.S. Nat. Acad. Sci., 54, 864 (1965).

'Burch, P. R. J., and Burwell, R. G., Quart. Rev. Biol., 40, 252 (1965).

${ }^{10}$ Cioli, D., and Baglioni, C., J. Mol. Biol., 15, 385 (1966).

${ }^{\prime}$ Salas, M., Smith, M. A., Stanley, W. M., Wahba, A. J., and Ochoa, S., J. Biol. Chem., 244, 3988 (1965).

${ }^{12}$ Terzaghi, E., Okada, Y., Streisinger, G., Tsugita, A., Inouye, M., and Emrich, J., Science, 150, 387 (1965).

${ }^{13}$ Guest, J. R., and Yanofsky, C., Nature, 210, 799 (1966).

+ Richardson, C. C., Schildkraut, C. L., and Kornberg, A., Cold Spr. Harb. Symp. Quant. Biol., 28, 9 (1963).

is Richardson, C. C., Lehman, I. R., and Kornberg, A., J. Biol. Chem., 239, 251 (1964).

${ }^{26}$ Richardson, C. C., Schildkraut, C. L., Aposhian, H. V., and Kornberg, A., J. Biol. Chem., 239, 222 (1964).

" Setlow, R. B., and Carrier, W. L., Pioc. U.S. Nat. Acad. Sci., 51, 226 (1964).

${ }^{18}$ Boyce, P. R., and Howard-Flanders, P., Proc. U.S. Nal. Acad. Sci., 51, 293 (1964).

is Pettijohn, D., and Hanawalt, P., J. Mol. Biol., 9, 395 (1964).

${ }^{29}$ Arber, W., Ann. Rev. Microbiol., 19, 365 (1965).

21 Speyer, J. F., Biochem. Biophys. Res. Commun., 21, 6 (1965).

Yanofsky, C., Cox, E. C., and Horn, V., Proc. D.S. Nat. Acad. Sci., 55, $274(1966)$.

\title{
SYNTHESIS OF EXCESS LIGHT CHAINS OF GAMMA GLOBULIN BY RABBIT LYMPH NODE CELLS
}

\author{
By Dr. ARNOLD L. SHAPIRO*, Dr. MATTHEW D. SCHARFF†, Dr. J. V. MAIZEL $\dagger$, jun., \\ and DR. J. W. UHR \\ Departments of Cell Biology and Medicine, Albert Einstein College of Medicine, Bronx, New York, and the Irvington House \\ Institute and Department of Medicine, New York University School of Medicine
}

Low molecular weight proteins immunologically related to the light chains of gamma globulin have been detected in normal human serum ${ }^{1,2}$ and urine ${ }^{1-7}$. In contrast to plasma cell tumours of mice and man which have been shown to produce excess $\mathrm{L}$ chains ${ }^{7}$, it is not certain whether the free $\mathrm{L}$ chains ${ }^{2}$ found in normal individuals result from de novo synthesis ${ }^{6}$ or the degradation of whole gamma globulin $^{3,4}$. This paper reports the synthesis and release of excess L chains by cells from the lymph nodes of hyperimmunized rabbits.

Popliteal lymph nodes were removed from rabbits 6-8 days after secondary stimulation with $T_{2}$ phage. Cells were teased from the nodes as previously described ${ }^{8}$ in Eagle's medium ${ }^{9}$ containing $1 / 50$ the normal amounts of amino-acids (in order to deplete the cellular pool). After pre-incubation at $37^{\circ} \mathrm{C}$ for $15 \mathrm{~min}$, the cells were exposed to carbon-14-labelled amino-acids (amino-acid-14 $\mathrm{C}$, u.l. mixture (New England Nuclear)) for either 30 or 60 min. Incorporation was terminated by chilling. The centrifuged cells were disrupted by five cycles of freezing and thawing in $0.01 \mathrm{M}$ tris-hydrochloric acid buffer $(p \mathrm{H} 8 \cdot 1)$, and cellular debris was removed by centrifugation at 1,500 r.p.m. for $15 \mathrm{~min}$. The cell lysates were treated at $37^{\circ} \mathrm{C}$ with 10 per cent acetic acid, 1 per cent sodium dodecyl sulphate (SDS), and $0.5 \mathrm{M}$ urea ${ }^{10}$. Half of each sample was reduced with 1 per cent 2-mercaptoethanol (ME). Samples were dialysed overnight at room temperature against 0.1 per cent SDS and $0.5 \mathrm{M}$ urea in $0 \cdot 01 \mathrm{M}$ phosphate buffer $p \mathrm{H} 7 \cdot 1$, and $0 \cdot 1$ per cent mercaptoethanol was added to the dialysis fluid of the pre-

* Special Fellow, National Institute of Neurological Diseases andBlindness. + Recipients of U.S. Public Health Service career development awards. viously reduced samples ${ }^{10}$. Electrophoresis of $0.3 \mathrm{ml}$. samples was carried out on 5 per cent acrylamide gels for $150 \mathrm{~min}$ at $4 \mathrm{~V} / \mathrm{cm}$. The gels were then extruded ${ }^{10}$ on to planchets which were dried and counted in a low background gas flow counter (Nuclear Chicago model 1050).

The electrophoretic mobility of whole $7 S$ gamma globulin, and of the component $\mathrm{H}$ and $\mathrm{L}$ chains, was determined by staining electropherograms of purified proteins treated in the same way as the cell lysates. Preliminary experiments confirmed that acetic acid, SDS, and urea did not dissociate purified $7 S$ gamma globulin whereas the addition of mercaptoethanol resulted in the complete dissociation into $\mathrm{H}$ and $\mathrm{L}$ chain $\mathrm{s}^{11,12}$. Purified H and L chains were prepared by 'Sephadex' chromatography of gamma globulin reduced with $\mathrm{ME}$ in the presence of SDS and urea.

An electropherogram of the intracellular proteins synthesized by rabbit lymph node cells during the first $30 \mathrm{~min}$ of exposure to carbon-14-labelled amino-acids is shown in Fig. 1. When the cell lysate was treated at low $p \mathrm{H}$ with SDS and urea but not mercaptoethanol (lowər panel of Fig. 1), there was a large peak representing whole $7 S$ gamma globulin and a smaller peak the migration of which was identical with that of $\mathrm{L}$ chains prepared by 'Sephadex' chromatography. No H chains are detectable above the background radioactivity due to cellular proteins. In the presence of mercaptoethanol (upper panel, Fig. 1) the peak representing whole gamma globulin disappeared, the amount of material in the $\mathrm{L}$ chain area increased approximately two-fold, and a new peak of intermediate migration appeared in the area where $\mathbf{H}$ chains were found on stained gels of 'Sephadex' purified 